\title{
KKN TEMATIK: PENGEMBANGAN MANAJEMEN PEMELIHARAAN SAPI POTONG PADA MASYARAKAT ASLI PAPUA DI DISTRIK KEBAR TAMBRAUW
}

\section{Thematic Community Service (KKN) Program: Development of Beef Cattle Raising Management for Indigenous Papuans in Kebar Tambrauw District}

\author{
Andoyo Supriyantono, Trisiwi W. Widayati, A.R. Ollong \\ Fakultas Peternakan Universitas Papua \\ Jl. Gunung Salju Amban Manokwari Papua Barat
}

Article history

Received: Jun 27, 2021;

Accepted: Sept 29, 2021

* Corresponding author:

E-mail:

andoyo@yahoo.com

DOI: https://doi.org/10.465

49/igkojei.v2i3.236

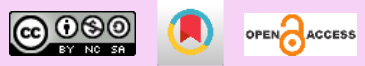

\begin{abstract}
Kebar has a very wide grazing area (1500 ha) but it is currently not managed properly and it can only accommodate 2 beef cattle with a bodyweight of $250 \mathrm{~kg}$. In 2011, the district was designated as a beef cattle barn and a million ranch area. However, this pasture is dominated by low-quality forage, causing a low body weight of beef cattle to be achieved at the productive age. The low productivity of beef is also caused by the lack of skill shown by the people concerning how to maintain good and correct beef cattle management procedures. The people do not understand how to properly manage and raise beef cattle due to a cultural shift from raising pigs to raising cows. Improving the skills of farmers in raising beef cattle can be done through thematic community service activities. The method used was to introduce superior forage with cultivation techniques that are easy and inexpensive to implement, while also being environmentally friendly. The results of the thematic community service showed that there was a positive change in the rearing of beef cattle from extensive to semi-intensive patterns. Farmers began to build housing units and plant superior grass for beef cattle feed needs. Community enthusiasm for counseling activities, demonstration plots, and training is increasing with the presence of farmers in every mentoring activity. Knowledge transfer between farmers is also carried out from one village to another that is not covered by the thematic KKN activities.
\end{abstract}

Keywords: Beef cattle; Farmers; Maintenance management; Thematic KKN.

\section{ABSTRAK}

Kebar memiliki padang penggembalaan yang sangat luas (1500 ha) akan tetapi tidak dikelola dengan baik dan hanya mampu menampung 2 ekor sapi potong dengan bobot badan $250 \mathrm{~kg}$. Pada tahun 2011, distrik ini ditetapkan sebagai kawasan lumbung ternak sapi potong dan kawasan sejuta ranch. Akan tetapi padang penggembalaan ini didominasi hijauan pakan dengan kualitas yang rendah sehingga menyebabkan rendahnya bobot badan sapi potong yang dicapai pada umur produktif. Produktivitas sapi potong yang tidak maksimum juga disebabkan oleh rendahnya keterampilan masyarakat dalam pemeliharaan sapi potong yang baik dan benar. Masyarakat belum memahami dengan benar bagaimana manajemen pemeliharaan sapi akibat adanya pergeseran budaya dari pemeliharaan ternak babi ke pemeliharaan ternak sapi potong. Peningkatkan keterampilan peternak dalam memelihara sapi potong dapat dilakukan antara lain melalui kegiatan KKN tematik. Metode yang dilakukan adalah dengan mengintroduksikan hijauan unggul dengan teknik budidaya yang mudah, murah dan ramah lingkungan. Hasil kegiatan menunjukkan bahwa terdapat perubahan positif dalam pemeliharaan sapi potong dari pola ekstensif menjadi semi intensif. Petani target mulai membuat kandang dan menanam rumput unggul untuk kebutuhan pakan sapi potong. Antusiasme masyarakat terhadap kegiatan penyuluhan, demplot dan pelatihan semakin meningkat dengan kehadiran petani 
dalam setiap kegiatan pendampingan. Transfer pengetahuan antar petani juga dilakukan dari satu kampung ke kampung lain yang tidak terjangkau kegiatan KKN tematik.

Kata Kunci: KKN tematik; Manajemen pemeliharaan; Petani; Sapi potong.

\section{PENDAHULUAN}

Distrik Kebar merupakan salah satu distrik di Kabupaten Tambrauw memiliki padang penggembalaan yang sangat luas (1500 ha) akan tetapi tidak dikelola dengan baik dan hanya mampu menampung 2 ekor sapi potong dengan asumsi bobot badan $250 \mathrm{~kg}$ (Supriyantono, et al. 2012). Pada tahun 2011, distrik ini ditetapkan sebagai kawasan lumbung ternak sapi potong dan kawasan sejuta ranch. Namun demikian ranch yang dimaksud merupakan padang penggembalaan dengan rumput alam dengan dominasi hijauan pakan yang rendah kualitas untuk ternak sapi. Dampak dari rendahnya kualitas dan kuantitas hijauan lapang adalah rendahnya bobot badan yang dicapai pada umur produktif. Hasil penelitian Supriyantono et al (2013) menunjukkan bahwa panjang badan, tinggi badan, lingkar dada, dan bobot badan sapi Bali dara di Kampung Janderau berturut-turut adalah 98,89 $\mathrm{cm}, 93,8 \mathrm{~cm}, 104 \mathrm{~cm}$ dan 159,4 kg dan ukuran-ukuran tersebut lebih rendah dari standar nasional untuk karakter yang sama pada sapi dara. Produktivitas sapi Bali yang tidak maksimum juga disebabkan oleh rendahnya keterampilan masyarakat dalam pemeliharaan sapi potong yang baik dan benar. Masyarakat belum memahami dengan benar bagaimana manajemen pemeliharaan sapi akibat adanya pergeseran budaya dari pemeliharaan ternak babi ke pemeliharaan ternak sapi potong. Oleh karena itu dibutuhkan sumber daya manusia yang terampil dan memiliki keterampilan di bidang peternakan guna membantu memberdayakan masyarakat dalam meningkatkan produktivitas sapi potong.

Mahasiswa sebagai tim KKN tematik bekerjasama dengan Dinas Peternakan Kabupaten Tambrauw Provinsi Papua Barat (sebagai mitra) melakukan pendampingan peningkatan keterampilan pemeliharaan ternak sapi di Kampung Janderauw, Manaria, dan Jafai. Usaha dalam meningkatkan produktivitas sapi potong di Distrik Kebar ini mutlak dilakukan agar masyarakat asli Papua dapat berdiri sejajar dengan masyarakat lain yang telah terlebih dahulu mengenal pemeliharaan sapi potong.

Sebagian besar penduduk bermata pencaharian sebagai petani dengan menanam kacang tanah dan bawang merah. Hasil kebun dipasarkan ke Kabupaten Manokwari secara individu karena penduduk belum mempunyai lembaga perekonomian seperti koperasi. Ternak yang dipelihara adalah babi, ayam, dan sapi. Introduksi sapi Bali yang dilakukan pada tahun 2014 melalui dana on top bantuan Presiden RI mengalami masalah dalam hal hijauan pakan dan manajemen pemeliharaan. Dengan adanya lahan tidur yang sangat luas, peternak di Kampung Janderauw dan Inam mempunyai potensi untuk berhasil dalam pemeliharaan sapi Bali jika mendapat bimbingan teknis yang baik dan benar dari ahli di bidangnya. 
Berdasarkan potensi-potensi tersebut maka kegiatan KKN tematik bertujuan sebagai berikut:

a. Petani mampu secara mandiri atau kelompok menyiapkan bibit rumput dan legume unggul untuk ditanam di lahan-lahan kosong;

b. Petani mampu secara mandiri menularkan pengetahuannya kepada petani di kampung lain untuk melakukan kegiatan yang serupa;

c. Adanya perbaikan sistem pemeliharaan sapi dari pemeliharaan secara ekstensif tanpa penambahan hijauan berkualitas menjadi pemeliharaan secara semi intensif dengan penambahan hijauan berkualitas;

d. Terjadi peningkatan partisipasi masyarakat dari 2 kelompok tani menjadi 5 kelompok tani;

\section{METODE}

Persiapan dan Pembekalan

\section{a. Mekanisme Pelaksanaan Kegiatan KKN TEMATIK}

Mekanisme kegiatan dilaksanakan dalam beberapa tahapan sebagai berikut:

- Tahap 1, memberikan pembekalan kepada mahasiswa peserta KKN TEMATIK yang diikuti oleh 30 orang mahasiswa dari berbagai disiplin ilmu (Produksi Ternak, Nutrisi dan Makanan Ternak, Perikanan dan Manajemen Sumberdaya Perairan);

- Tahap 2, pembagian lokasi sasaran KKN TEMATIK bagi setiap mahasiswa;

- Tahap 3, pembagian peralatan dan perlengkapan kepada mahasiswa;

- Tahap 4, penempatan mahasiswa di lapangan;

- Tahap 5, pelaksanaan kegiatan di lapangan;

- Tahap 6, pelaksanaan monitoring dan evaluasi yang dilakukan pada pertengahan kegiatan dan akhir kegiatan;

- Tahap 7, penarikan mahasiswa dari lokasi sasaran untuk kembali ke kampus.

b. Materi Persiapan dan Pembekalan KKN TEMATIK

Materi yang perlu diberikan kepada mahasiswa dalam pembekalan KKN TEMATIK terutama tentang bahan pakan untuk sapi potong yang baik, meliputi:

(1). Pengenalan rumput dan legume unggul

(2). Penanaman rumput dan legume

(3). Pemeliharaan sapi potong yang baik dan benar

c. Jadwal Pelaksanaan Kegiatan KKN TEMATIK

Kegiatan KKN TEMATIK mahasiswa adalah 2,5 - 3 bulan yang terdiri dari persiapan sampai dengan penempatan mahasiswa di lapang selama 2 (dua) minggu; kegiatan efektif di lapang selama 2 (dua) bulan; pembuatan laporan dan penyampaian laporan (termasuk seminar, diskusi, dan perbaikan laporan) selama 2 (dua) minggu. Selama di lapang mahasiswa melakukan kegiatan: a. 
Bimbingan teknis pemeliharaan sapi potong; b. Teknik penanaman rumput dan legume; c. Penyuluhan kepada peternak sapi

Program KKN diikuti oleh 23 mahasiswa dari berbagai bidang ilmu atau program studi yang tersebar di kampung-kampung masyarakat asli Papua yaitu di Kampung Jafai, Manaria, dan Janderau, Distrik Kebar. Sebanyak 8 orang mahasiswa ditempatkan di Kampung Jafai, 6 orang di kampung Manaria, dan 9 orang di Kampung Janderau. Volume pekerjaan setiap mahasiswa dihitung berdasarkan Jam Kerja Efektif Mahasiswa (JKEM) yakni sebanyak 36 JKEM per minggu atau 144 JKEM per bulan (seperti disajikan pada Tabel 1).

\section{Tabel 1. Volume Pekerjaan}

\begin{tabular}{|c|c|c|c|c|}
\hline No. & Nama Pekerjaan & Program & $\begin{array}{c}\text { Volume } \\
(\text { JKEM) }\end{array}$ & Keterangan \\
\hline \multirow[t]{3}{*}{1.} & \multirow{3}{*}{$\begin{array}{l}\text { Peningkatan produktivitas } \\
\text { ternak sapi potong melalui } \\
\text { introduksi teknologi tepat } \\
\text { guna pada masyarakat asli } \\
\text { Papua di Distrik Kebar } \\
\text { Tambrauw Papua Barat }\end{array}$} & $\begin{array}{l}\text { 1. Penyuluhan kepada } \\
\text { peternak pada } 3 \text { kampung }\end{array}$ & $6 \mathrm{jam} / \mathrm{minggu}$ & $\begin{array}{l}\text { 6-9 orang per } \\
\text { kelompok }\end{array}$ \\
\hline & & $\begin{array}{l}\text { 2. Bimbingan teknis } \\
\text { pemeliharaan sapi potong }\end{array}$ & $4 \mathrm{jam} /$ minggu & \\
\hline & & $\begin{array}{l}\text { 3. Penanaman rumput dan } \\
\text { legume di } 3 \text { kampung }\end{array}$ & $18 \mathrm{jam} /$ minggu & \\
\hline \multirow[t]{4}{*}{2.} & \multirow[t]{2}{*}{$\begin{array}{l}\text { Peningkatan kualitas sarana } \\
\text { dan prasarana kampung }\end{array}$} & $\begin{array}{l}\text { 1. Perbaikan monografi desa, } \\
\text { nama jalur dan papan } \\
\text { nama yang dibutuhkan }\end{array}$ & $4 \mathrm{jam} / \mathrm{minggu}$ & $\begin{array}{l}\text { 6-9 orang per } \\
\text { kelompok }\end{array}$ \\
\hline & & $\begin{array}{l}\text { 2. Menggerakkan } \\
\text { masyarakat untuk } \\
\text { melakukan kerja gotong } \\
\text { royong di fasilitas umum }\end{array}$ & $4 \mathrm{jam} /$ minggu & \\
\hline & \multirow{2}{*}{\multicolumn{2}{|c|}{ TOTAL VOLUME KEGIATAN }} & $\begin{array}{l}36 \quad \text { JKEM/ } \\
\text { minggu atau } 144\end{array}$ & $\begin{array}{l}23 \text { orang } \\
\text { mahasiswa }=\end{array}$ \\
\hline & & & JKEM per bulan & $\begin{array}{l}4.320 \mathrm{JKEM} / \\
\text { bulan }\end{array}$ \\
\hline
\end{tabular}

\section{HASIL DAN PEMBAHASAN}

Program Kerja

Secara umum program kerja KKN TEMATIK di tiga kampung (Jafai, Manaria dan Janderau) seperti disajikan pada Tabel 2.

Tabel 2. Program Kerja KKN TEMATIK di Kampung Jafai, Manaria, dan Janderau

\begin{tabular}{llc}
\hline \multirow{2}{*}{ No } & \multicolumn{1}{c}{ Bidang Program } & \multicolumn{2}{c}{ Jenis Program Kerja } \\
\cline { 3 - 3 } 1. & Peternakan & Utama \\
a. Teknik Pemeliharaan Sapi & $\mathrm{v}$ \\
b. Teknik Pemeliharaan Babi & $\mathrm{v}$ \\
c. Pengenalan Pakan Ternak Sapi & $\mathrm{v}$ \\
d. Penyuluhan Biogas & $\mathrm{v}$ \\
f. Pembuatan Pupuk Kompos & $\mathrm{v}$ \\
g. Pembuatan Kandang Sapi & $\mathrm{v}$ \\
h. Penanaman Rumput Raja Dan Gajah & $\mathrm{v}$ \\
\end{tabular}




\begin{tabular}{|c|c|c|c|}
\hline \multirow{2}{*}{ No } & \multirow{2}{*}{ Bidang Program } & \multicolumn{2}{|c|}{ Jenis Program Kerja } \\
\hline & & Utama & Bantu \\
\hline \multirow[t]{2}{*}{2.} & Sarana dan Prasarana & & \\
\hline & Pembuatan papan fasilitas umum dan saringan air & & $\mathrm{v}$ \\
\hline \multirow[t]{3}{*}{3.} & Pertanian & & \\
\hline & a. Budidaya kacang tanah dan kangkung & & $\mathrm{V}$ \\
\hline & b. Bimbingan pengolahan hasil pertanian & & $\mathrm{v}$ \\
\hline \multirow[t]{3}{*}{4.} & Ekonomi & & \\
\hline & a. Pengajaran pembukuan sederhana & & $\mathrm{v}$ \\
\hline & b. Penyuluhan peluang bisnis & & $\mathrm{v}$ \\
\hline \multirow[t]{5}{*}{5.} & Pendidikan & & \\
\hline & a. Calistung (membaca, menulis, dan menghitung) & & $\mathrm{V}$ \\
\hline & b. Pengajaran les tambahan anak sekolah & & $\mathrm{v}$ \\
\hline & c. Pengadaan posko baca & & $\mathrm{v}$ \\
\hline & d. Pengadaan les pengetikan komputer & & $\mathrm{v}$ \\
\hline \multirow[t]{5}{*}{6.} & Kesehatan dan lingkungan hidup & & \\
\hline & a. Pembuatan demplot tempat sampah & & $\mathrm{v}$ \\
\hline & b. Pemberian simbolis tanaman obat & & $\mathrm{v}$ \\
\hline & c. Sosialisasi arti hidup sehat & & $\mathrm{v}$ \\
\hline & d. Jumat bersih & & $\mathrm{v}$ \\
\hline \multirow[t]{2}{*}{7.} & Administrasi dan kependudukan desa & & \\
\hline & Pembuatan monografi desa & & $\mathrm{v}$ \\
\hline \multirow[t]{3}{*}{8.} & Program lain-lainnya & & \\
\hline & a. Bakti sosial & & $\mathrm{v}$ \\
\hline & b. Perayaan HUT RI ke-71 & & $\mathrm{v}$ \\
\hline \multirow[t]{2}{*}{9.} & Kehutanan & & \\
\hline & Penanaman kayu besi secara simbolis & & $\mathrm{v}$ \\
\hline
\end{tabular}

Tabel 2. menunjukkan bahwa terdapat 9 program KKN TEMATIK di Kampung Jafai, Manaria, dan Janderau. Satu program utama yaitu di bidang peternakan dilakukan guna mendampingi masyarakat dalam pemeliharaan sapi potong dan jenis ternak lain. Pendampingan perlu dilakukan karena masyarakat masih dalam taraf uji coba dalam pemeliharaan sapi potong. Secara turuntemurun masyarakat asli Papua memelihara babi guna kepentingan sosial budaya mereka. Adanya pergeseran budaya pada masyarakat asli Papua menyebabkan mereka mulai melakukan pemeliharaan sapi potong. Oleh karena itu kehadiran para mahasiswa melalui kegiatan KKN TEMATIK diharapkan membantu masyarakat asli Papua pada pemeliharaan sapi potong mereka. Delapan program lain adalah program bantu yang dibuat oleh mahasiswa bersama-sama dengan masyarakat guna menunjang program utama.

Pelaksanaan Kegiatan

1. Penyuluhan Teknik Pemeliharaan Sapi dan Babi

- Permasalahan: Pemeliharaan hewan ternak masih bersifat tradisional 
- Tujuan: Media informasi petunjuk praktis memelihara ternak agar dapat dipahami dan diterapkan oleh peternak

- Hasil Kegiatan: Perubahan pola pikir masyarakat dalam memelihara hewan ternak mereka

- Hambatan/Kendala: Rendahnya partisipasi masyarakat

- Sasaran: Masyarakat Kampung Jafai, Janderau, dan Manaria Distrik Kebar Kabupaten Tambraw

2. Penyuluhan Pengenalan Pakan Ternak Sapi

- Permasalahan: Kurangnya pengetahuan masyarakat tentang pakan ternak sapi

- Tujuan: Media informasi pengenalan pakan ternak sapi

- Hasil Kegiatan: Pengetahuan akan pakan ternak sapi bertambah

- Hambatan/Kendala: Rendahnya partisipasi masyarakat

- Sasaran: Masyarakat Kampung Jafai, Janderau, dan Manaria Distrik Kebar Kabupaten Tambrauw

3. Pembuatan Kandang Sapi

- Permasalahan: Tidak ada masyarakat yang mempunyai kandang sapi

- Tujuan: Menjadi percontohan dalam pembuatan kandang sapi

- Hasil Kegiatan: adanya keikutsertaan masyarakat dalam membuat kandang

- Hambatan/Kendala: Rendahnya partisipasi masyarakat

- Sasaran: Masyarakat Kampung Jafai, Janderau dan Manaria Distrik Kebar Kabupaten Tambrauw

4. Penanaman Rumput

- Permasalahan: Minimnya pengetahuan masyarakat tentang rumput raja dan gajah

- Tujuan: Media pengajaran masyarakat tentang rumput

- Hasil Kegiatan: Masyarakat mau bekerja sama dalam penanaman rumput

- Hambatan/Kendala: Rendahnya partisipasi masyarakat

- Sasaran: Masyarakat Kampung Jafai, Janderau dan Manaria Distrik Kebar Kabupaten Tambrauw

5. Sarana dan Prasarana

- Permasalahan: Tidak ada papan fasilitas umum (khususnya papan nama jalan) dan saringan air.

- Tujuan: Membantu masyarakat membuat papan fasilitas umum (khususnya papan nama jalan) dan saringan air.

- Hasil Kegiatan: Berhasil bekerja sama dengan masyarakat dalam pembuatan papan nama jalan \& saringan air

- Hambatan/Kendala: Tidak ada

- Sasaran: Masyarakat Kampung Jafai, Janderau, dan Manaria Distrik Kebar Kabupaten Tambrauw. 


\section{Pertanian}

- Permasalahan: Kurangnya masyarakat membudidayakan kangkung \& kacang tanah serta minimnya pengetahuan masyarakat dalam mengolah hasil perkebunan mereka.

- Tujuan: Mengajarkan masyarakat budidaya kacang tanah dan kangkung serta mengajarkan masyarakat mengolah hasil perkebunan mereka

- Hasil Kegiatan: Berhasil mengarahkan masyarakat dalam mengolah hasil pertanian mereka \& menginfokan pembudidayaan kangkung dan kacang tanah

- Hambatan/Kendala: Tidak semua masyarakat berperan dalam budidaya kacang tanah dan kangkung serta ikut dalam bimbingan pengolahan hasil kebun

- Sasaran: Masyarakat Kampung Jafai Distrik Kebar Kabupaten Tambrauw

7. Kehutanan

- Permasalahan: Banyaknya penebangan kayu secara liar

- Tujuan: Memberikan himbauan ke masyarakat untuk tidak menebang kayu sembarangan

- Hasil Kegiatan: Berhasil mengingatkan masyarakat tentang penebangan pohon secara liar.

- Hambatan/Kendala: Tidak ada

- Sasaran: Masyarakat Kampung Jafai, Janderau, dan Manaria Distrik Kebar Kabupaten Tambrauw (berprofesi sebagai penebang kayu)

8. Ekonomi

- Permasalahan: Ketidaktahuan masyarakat tentang pembukuan keuangan dan minimnya semangat berbisnis

- Tujuan: Mengadakan pengajaran pembukuan sederhana dan menyuluhkan tentang peluang bisnis

- Hasil Kegiatan: adanya antusias masyarakat tentang cara berbisnis dan partisipasi masyarakat dalam menerima pengajaran pembukuan sederhana

- Hambatan/Kendala: Tidak ada

- Sasaran: Masyarakat Kampung Jafai Distrik Kebar Kabupaten Tambrauw

9. Pendidikan

- Permasalahan: Minimnya semangat belajar murid sekolah dan rendahnya kebiasaan membaca buku.

- Tujuan: Meningkatkan semangat belajar murid sekolah dan memunculkan kebiasaan membaca buku.

- Hasil Kegiatan: adanya peningkatan kecerdasan peserta didik dan telah muncul kebiasaan membaca buku.

- Hambatan/Kendala: Penyesuaian dengan sikap murid sekolah yang masih malu-malu.

- Sasaran: Anak sekolahan di Kampung Jafai Distrik Kebar Kabupaten Tambrauw. 


\section{Luaran yang Dicapai}

a. Petani mampu secara mandiri atau kelompok menyiapkan bibit rumput dan legume unggul untuk ditanam di lahan-lahan kosong. Bukti kegiatan penanaman hijauan oleh petani setelah adanya demplot oleh mahasiswa seperti Gambar 1.
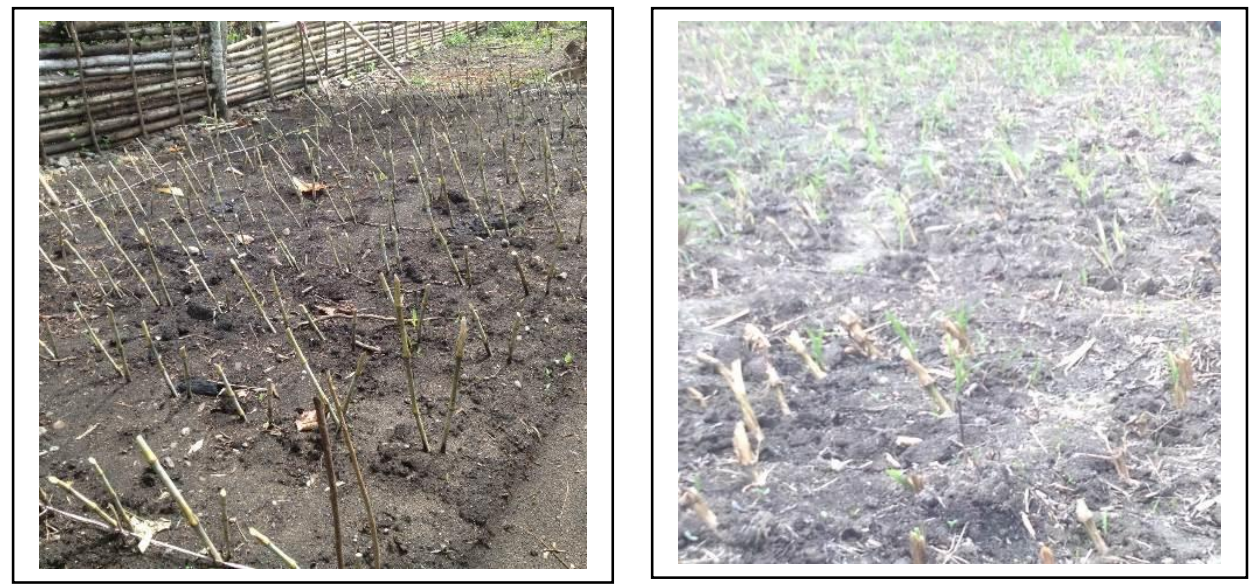

Gambar 1. Penanaman Hijauan Unggul oleh Petani untuk Pakan Sapi

b. Petani mampu secara mandiri menularkan pengetahuannya kepada petani di kampung lain untuk melakukan kegiatan yang serupa. Beberapa petani telah menularkan pengetahuannya pada petani di kampung lain yang tidak terjangkau program KKN TEMATIK. Gambar 2 merupakan bukti bahwa petani di kampung lain telah mulai dengan intensifikasi sapi potong.

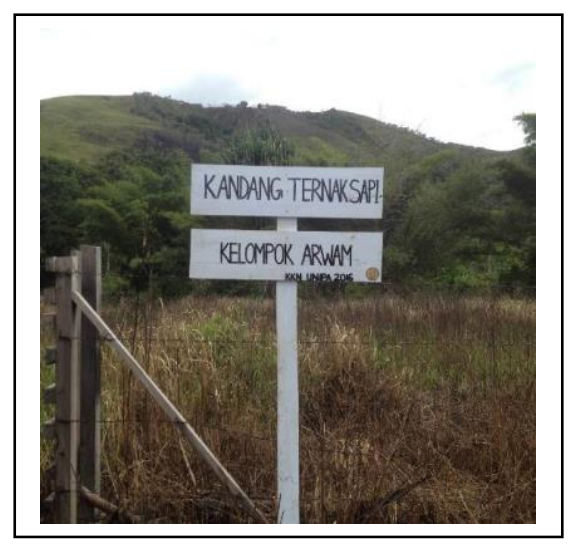

Gambar 2. Kandang Sapi pada Kelompok Arwam di Kampung Anjai

c. Adanya perbaikan sistem pemeliharaan sapi dari pemeliharaan secara ekstensif tanpa penambahan hijauan berkualitas menjadi pemeliharaan secara semi intensif dengan penambahan hijauan berkualitas. Petani mulai memagari dan menanami lahan-lahan kosong dengan hijauan unggul guna pemeliharaan sapi potong yang intensif, seperti yang disajikan pada Gambar 3. 

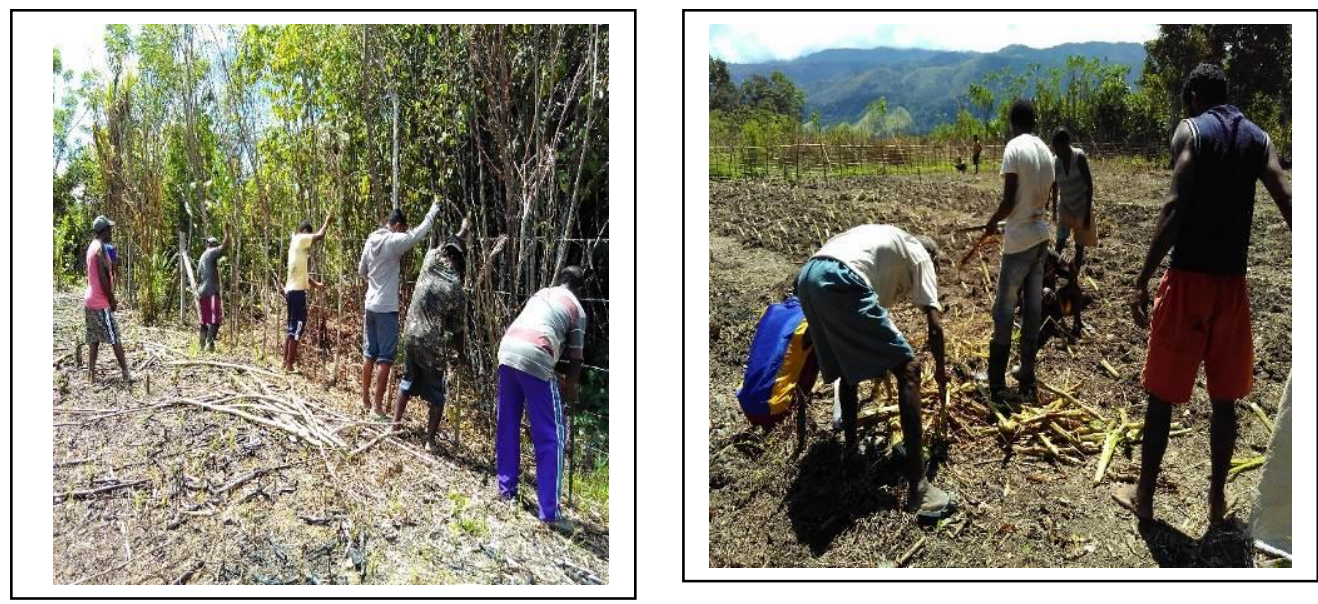

Gambar 3. Pemagaran dan penanaman Rumput Unggul

d. Terjadi peningkatan partisipasi masyarakat dari 2 kelompok tani menjadi 5 kelompok tani. Ini terlihat di akhir kegiatan KKN TEMATIK, bahwa kelompok tani yang terlibat dalam kegiatan penyuluhan semakin meningkat. Gambar 4 menunjukkan kegiatan penyuluhan yang diikuti perwakilan dari 5 kelompok tani.
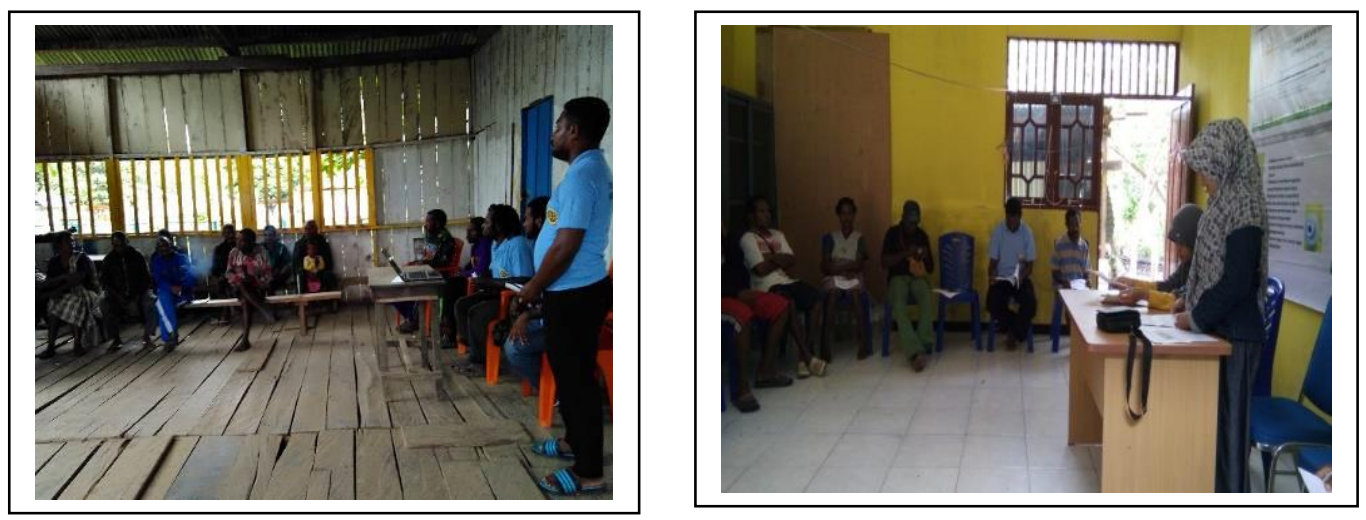

Gambar 4. Peningkatan partisipasi masyarakat dalam kegiatan di bidang peternakan

\section{KESIMPULAN}

Dari hasil kegiatan KKN TEMATIK di tiga kampung (Jafai, Manaria, dan Jandurau) maka dapat disimpulkan bahwa terjadi perubahan dalam pemeliharaan sapi potong dari sistem ekstensif menjadi semi intensif. Sapi potong mulai dikandangkan dan diberi hijauan unggul baik berupa rumput maupun legume. Masyarakat mulai menyadari pentingnya tambahan hijauan unggul untuk meningkatkan produktivitas sapi potong. Pengetahuan petani terhadap kesehatan sapi, siklus reproduksi dan pemilihan bibit yang baik juga mengalami perubahan yang positif.

\section{DAFTAR PUSTAKA}

Mariyono dan Romjali, E., 2007. Petunjuk teknis teknologi inovasi Pakan murah untuk usaha pembibitan sapi potong. Pusat Penelitian dan Pengembangan Peternakan. Jakarta. 
Soemarmi, A. Musofie, and N. K. Wardhani. 1985. Effect of sugar cane top on daily weight gain of male Bali cattle. Proc. Seminar the Use of Sugarcane Waste for Animal Feed. Grati. Center Research in Animal Science.

Supriyantono, A., O. Yoku, T.W. Widayanti, dan I. Sumpe, 2012. Pengembangan Village Breeding Center Sapi Bali dalam Mendukung Program Kecukupan Daging Sapi di Papua Barat. Laporan Penelitian Prioritas Nasional Masterplan Percepatan dan Perluasan Pembangunan Ekonomi Indonesia 2011 - 2025 (Penprinas MP3EI 2011 - 2025) 